Article

\title{
Preparation of Black Ceramic Tiles Using Waste Copper Slag and Stainless Steel Slag of Electric Arc Furnace
}

\author{
Mengke Liu ${ }^{1,2,3}$, Guojun Ma ${ }^{1,2,3, * \mathbb{C}}$, Xiang Zhang ${ }^{1,2,3}$, Junjie Liu ${ }^{1,2,3}$ and Qiang Wang ${ }^{1,2,3}$ \\ 1 The State Key Laboratory of Refractories and Metallurgy, Wuhan University of Science and Technology, \\ Wuhan 430081, China; liumengke@wust.edu.cn (M.L.); zx91@wust.edu.cn (X.Z.); \\ qwe1023215227@163.com (J.L.); wangqiang58@wust.edu.cn (Q.W.) \\ 2 Key Laboratory for Ferrous Metallurgy and Resources Utilization of Ministry of Education, Wuhan \\ University of Science and Technology, Wuhan 430081, China \\ 3 Hubei Provincial Key Laboratory of New Processes of Ironmaking and Steelmaking, Wuhan University of \\ Science and Technology, Wuhan 430081, China \\ * Correspondence: gma@wust.edu.cn; Tel.: +86-27-6886-2810
}

Received: 27 December 2019; Accepted: 23 January 2020; Published: 8 February 2020

\begin{abstract}
Copper slag and stainless steel slag of Electric Arc Furnace (EAF) are two typical metallurgical solid wastes, which contain a large number of valuables, such as $\mathrm{Fe}, \mathrm{Cr}$, and $\mathrm{Cu}$. The transition metal elements in the waste slags, such as $\mathrm{Cr}$ and Fe, can be recycled as the coloring ions in the black ceramic tile. In this study, the $\mathrm{Fe} / \mathrm{Cr}$ molar ratio in the raw materials of copper slag and stainless steel slag was adjusted, and the black ceramic tile was subsequently prepared by sintering. The results show that the optimum process parameters for the preparation of black ceramic tiles are the $\mathrm{Fe} / \mathrm{Cr}$ molar ratio of 2.0 , the sintering temperature of $1150{ }^{\circ} \mathrm{C}$, and the sintering time of $30 \mathrm{~min}$. The compressive strength of the black ceramic tile at optimum sintering conditions exceeds the minimum compressive strength of the Chinese national standard for standard polished tiles, and the concentrations of harmful elements, for example, $\mathrm{Cr}, \mathrm{Cu}, \mathrm{Ni}, \mathrm{As}, \mathrm{Zn}, \mathrm{Pb}$, and $\mathrm{Cr}(\mathrm{VI})$ are within the regulation thresholds specified by the Chinese national standard.
\end{abstract}

Keywords: Metallurgical waste; Copper slag; Stainless steel slag; Black ceramic tile

\section{Introduction}

According to the U.S. Geological Survey (USGS), the total global mine production of copper in 2018 was 21,000 thousand metric tons [1]. The International Copper Study Group (ICSG) predicted the growth of $2.8 \%$ in 2019 and $1.2 \%$ in 2020 as for global refined copper production [2], and China will continue to be the world's top contributor to world refined copper growth in 2020 [3].

Copper slag is an industrial by-product of copper smelting and refining from copper ores [4]. Typically, approximately 2.2-3.0 tons of copper slag can be obtained by producing one ton of copper [5], and it is estimated that 24.6 million tons of copper slag is produced annually [6]. There are $30-50 \mathrm{wt} \%$ $\mathrm{Fe}, 0.5-2.1 \mathrm{wt} \% \mathrm{Cu}, 25-35 \mathrm{wt} \% \mathrm{SiO}_{2}$ and $\sim 1 \mathrm{wt} \% \mathrm{Zn}$ in the copper slag [7-10]. Therefore, the recovery of valuable components in copper slag is of great significance.

In recent years, the output of the stainless steel of Electric Arc Furnace (EAF) has also increased continuously. According to the statistical reports of the International Stainless Steel Forum (ISSF), the global stainless steel melts shop production increased $5.5 \%$ amount to 50.7 million tons in 2018, of which the Chinese stainless steel melt shop contributed about $52.7 \%$ [11].

The stainless steel slag of EAF is a by-product of the stainless steel smelting process in EAF [12]. Generally, the stainless steel slag of EAF contains $40-50 \% \mathrm{CaO}, 5-10 \% \mathrm{Fe}_{2} \mathrm{O}_{3},<10 \% \mathrm{Cr}_{2} \mathrm{O}_{3}$, and $<2 \%$ 
$\mathrm{MnO}$ [13-18], which indicates that it has potential recovery value. However, stainless steel slag also consists of lots of hazardous elements, such as $\mathrm{Cr}, \mathrm{Pb}, \mathrm{Ni}$, and $\mathrm{Cd}$, which are harmful to the health of humans and the environment [19]. Therefore, the comprehensive utilization of stainless steel slag of EAF is of great significance to the economy and environment.

Black ceramic tiles are widely used in the building and decoration industries. In the traditional production process of black ceramic tile, the price of black ceramic tiles is closely connected with the price of $\mathrm{Co}_{2} \mathrm{O}_{3}$, which limits the development of cobalt-containing black ceramic products. However, by selecting the appropriate process parameters, Co-free black ceramic tiles with good performance can be prepared with industrial by-products, such as steel slag and dust, vanadium tailing, and copper slag. It can not only reduce production costs and improve economic efficiency, but also reduce environmental pollution caused by industrial wastes, which provides a new way for industrial waste recycling [20-23].

Pigments can be prepared from brick clay and metallurgical dust, and then the pigment was applied to ceramic tiles [24]. Mixtures with engobe were fired at $900^{\circ} \mathrm{C}$, whereas ceramic tiles with pigment were fired at $1060^{\circ} \mathrm{C}$. The pigment was well combined with the ceramic surface. Meanwhile, the variation of proportion of pigment to the ceramic body influence the final coloration performance of ceramic tiles.

Vanadium tailings and leather sludge can be used to prepare the black ceramic pigment [25]. The pigments based on the $\left(\mathrm{Fe}_{0.6} \mathrm{Cr}_{0.4}\right)_{2} \mathrm{O}_{3}$ were prepared by a common solid-state reaction method. The optimum process parameters are the $\mathrm{Fe} / \mathrm{Cr}$ molar ratio of 2.0 , the sintering temperature of $1200^{\circ} \mathrm{C}$ and $40 \mathrm{wt} \%$ vanadium tailing. The coloring properties of prepared ceramic pigments with vanadium tailing were similar to the commercial black pigments.

Moreover, hematite tailings can be combined with quartz sand and kaolin to produce black ceramic tiles [26,27]. The sintering temperature and tailings ratio have significant effects on the properties of black ceramic tiles. The optimum process parameters for the preparation of black ceramic tiles are the addition of $55-65 \mathrm{wt} \%$ hematite tailings, $25 \mathrm{wt} \%$ kaolin, and $10-20 \mathrm{wt} \%$ quartz sand, the sintering temperature of $1200{ }^{\circ} \mathrm{C}$, and the sintering time of $30 \mathrm{~min}$. The properties of the prepared ceramic tiles reach the Chinese standard specifications (GB/T4100-2006) of ceramic tiles.

Steel slag can also be used to prepare for ceramic tiles [28]. The mixture of $60 \%$ clay, quartz, feldspar, talc, and $40 \%$ of steel slag can be sintered at $1200-1220{ }^{\circ} \mathrm{C}$. The ceramic tile samples at optimum sintering conditions have good properties, with the flexural strength of $143 \mathrm{MPa}$, water absorption of $0.02 \%$, and linear shrinkage of $8.8 \%$.

According to the coloring mechanism of Fe-Cr spinel black pigment, Zhang et al. [29] added reagent grade $\mathrm{Cr}_{2} \mathrm{O}_{3}$ into the stainless steel dust and adjusted the $\mathrm{Fe} / \mathrm{Cr}$ molar ratio in the materials. Thereafter, it was used to prepare black pigment. Ceramic tiles were prepared by adding the obtained black pigment. The optimum process parameters for the preparation of black ceramic tiles are the addition of $8 \mathrm{wt} \%$ black pigment, the sintering temperature of $1200{ }^{\circ} \mathrm{C}$, and the sintering time of $30 \mathrm{~min}$. The compressive strength of the black ceramic tiles and the concentrations of harmful elements are within the regulation thresholds specified by the Chinese national standard.

Generally, the traditional technology of preparing black ceramic tile is a two-step process, i.e., black pigment preparation stage and ceramic tiles preparation stage. Note that $\mathrm{Fe}$ - and $\mathrm{Cr}$-containing black ceramic pigments are the most extensively used pigment in porcelain tile production. $\mathrm{SiO}_{2}$ and $\mathrm{Al}_{2} \mathrm{O}_{3}$ are the major components of the ceramic matrix [20]. Copper slag and EAF stainless steel slag are rich in oxides of $\mathrm{SiO}_{2}, \mathrm{Al}_{2} \mathrm{O}_{3}, \mathrm{Fe}_{2} \mathrm{O}_{3}$, and $\mathrm{Cr}_{2} \mathrm{O}_{3}$, and can be potentially prepared black ceramic tiles directly. This can not only reduce energy consumption and production costs, but also reduce the environmental hazards of heavy metals in the slag and recycle the valuable metals in the slag.

In this study, copper slag and stainless steel slag of EAF were characterized by ICP-AES, SEM, TG/DTA, and XRD. Then, the Fe-Cr-based black ceramic tiles were prepared with copper slag and stainless steel slag by adjusting the $\mathrm{Fe} / \mathrm{Cr}$ molar ratio in the mixture. The effects of the process parameters such as $\mathrm{Fe} / \mathrm{Cr}$ molar ratio, sintering temperature and sintering time on the microstructure, phase composition, coloration performance and compressive strength of the ceramic tile were studied 
in order to provide theoretical and experimental basis for the harmless and value-added application of copper slag and stainless steel slag of EAF.

\section{Experimental}

\subsection{Raw Materials}

The waste copper slag was collected from a copper smelting plant in central China where the copper slag was impoverished and floated for copper recovery. The stainless steel slag of EAF was sampled in a domestic stainless steel mill.

\subsection{Characterization}

\subsubsection{Chemical Composition, Crystalline Phase, and Microstructure}

The chemical compositions of copper slag and stainless steel slag were analyzed by inductively coupled plasma emission spectrometer (ThemoElemental IRIS Advantage Radial, America). The crystalline phases were identified using an X-ray powder diffractometer (PANalytical X'Pert PRO MPD, Netherlands) with $\mathrm{Cu} K \alpha$ radiation at a tube voltage of $40 \mathrm{kV}$, current of $40 \mathrm{~mA}$ and 2 theta scanning ranging from $15^{\circ}$ to $80^{\circ}$. The microstructures of the waste slags were examined with a field emission scanning electron microscope (FEI Nova NanoSEM400, FEI, Hillsboro, Oregon, America).

\subsubsection{Thermogravimetric Test}

Approximately $10 \mathrm{mg}$ copper slag and $10 \mathrm{mg}$ stainless steel slag were, respectively, weighed and heated to $1200^{\circ} \mathrm{C}$ at the heating speed of $10^{\circ} \mathrm{C} / \mathrm{min}$ in the air atmosphere using a thermogravimetric analyzer (NETZSCH STA 449F3, Selb, Germany) to monitor the relationship between the gravity and temperature of copper slag and EAF stainless steel slag.

\subsection{Preparation of Black Ceramic Tile}

The copper slag and the EAF stainless steel slag were ground to a particle size of 200 mesh or less using a planetary ball mill (QM-3SP4, Nanjing Chi Shun Technology Development Co., Ltd, Nanjing, China) and dried in an oven at $100{ }^{\circ} \mathrm{C}$ for 24 hours. It was subsequently mixed in a certain ratio ( $\mathrm{Fe} / \mathrm{Cr}$ molar ratio is $0.5-2.5$ ), and pressed into cylindrical specimens with a diameter of $\sim 2 \mathrm{~cm}$ using a conventional press at a pressure of $25 \mathrm{MPa}$. Then, the samples were placed in a muffle furnace (SX2-10-13, Shanghai Shi Yan Electric Furnace Co., Ltd, Shanghai, China) and sintered in an air atmosphere at ambient pressure to obtain black ceramic tile samples. The experimental process parameters are shown in Table 1 . The heating speed of the furnace was about $10{ }^{\circ} \mathrm{C} / \mathrm{min}$ and the samples were cooled down to room temperature in the muffle furnace. Subsequently, the long-term leaching behavior and physical properties of ceramic cylinders were tested.

Table 1. The process parameters of black ceramic tile production.

\begin{tabular}{ccc}
\hline Fe/Cr Molar Ratio & Sintering Temperature $\left({ }^{\circ} \mathbf{C}\right)$ & Sintering Time (min) \\
\hline $0.5,1.0,1.5,2.0,2.5$ & $1100,1125,1150,1175,1200$ & $15,30,45,60,90$ \\
\hline
\end{tabular}

\subsection{Coloration Performance of Black Ceramic Tiles}

The $L^{*}, a^{*}$, and $b^{*}$ color space developed by the International Commission on Illumination (CIE) is a device-independent color model. In this system, $L^{*}$ is the degree of lightness and darkness of the color in relation to the scale extending from white $\left(L^{*}=100\right)$ to black $\left(L^{*}=0\right) . a^{*}$ is the degree of green $\left(-a^{*}\right)$ and red $\left(+a^{*}\right), b^{*}$ is the degree of blue $\left(-b^{*}\right)$ and yellow $\left(+b^{*}\right)$ [25]. In this work, the color of the ceramic tile was characterized by $L^{*}, a^{*}$, and $b^{*}$ color space, and the $L^{*}, a^{*}$, and $b^{*}$ values of the tile 
were measured using a portable chromatic aberration meter (SC10 NR10QC). For black ceramic titles, the closer $L^{*}, a^{*}$, and $b^{*}$ are to 0 , the better the coloration performance.

\subsection{Leaching Test and Compression Resistance of Black Ceramic Tiles}

In this study, the environmental protection industry standard of China HJ/T299-2007 [30] was adopted to carry out the leaching test of toxic substances in ceramic tiles. In this test, concentrated nitric acid and concentrated sulfuric acid with the mass ratio of 1:2 were firstly added to deionized water to prepare the leaching agent with the $\mathrm{pH}$ of $3.2 \pm 0.05$. The powder sample and the leaching agent were added to a $100 \mathrm{ml}$ glass bottle and sealed to ensure the solid and liquid ratio of 1:10 (g/mL). At $23 \pm 2{ }^{\circ} \mathrm{C}$, the mixture was shaken by an end-over-end homogenizer with the rotation speed of $30 \pm 2 \mathrm{r} / \mathrm{min}$ for $18 \pm 2 \mathrm{~h}$. After filtration, the contents of $\mathrm{Cr}, \mathrm{Cu}, \mathrm{Ni}, \mathrm{As}, \mathrm{Zn}, \mathrm{Pb}$, and $\mathrm{Cr}(\mathrm{VI})$ in the leachate were measured. The concentration of $\mathrm{Cr}(\mathrm{VI})$ was determined by spectrophotometry (Model 722 spectrophotometer, Beijing Century Science Instrument Co., Ltd, Beijing, China), whereas the concentration of other leachable toxic elements was determined by the ICP-AES. The ceramic tile was also subjected to a compression test using a hydraulic universal test machine (WE-30, Tai Tian machinery Jiangsu Co., Ltd, Jiangsu, China).

\section{Results and Discussion}

\subsection{Characterization of Copper Slag and Stainless Steel Slag}

\subsubsection{Chemical Composition and Crystalline Phases}

The chemical compositions of EAF stainless steel slag and copper slag are shown in Table 2. The main chemical constituents of copper slag used in this study are $\mathrm{Fe}_{2} \mathrm{O}_{3}$ and $\mathrm{SiO}_{2}$, the content of them are $52.69 \%$ and $33.44 \%$, respectively, whereas the main chemical constituents of stainless steel slag are $\mathrm{SiO}_{2}, \mathrm{CaO}$, and $\mathrm{Cr}_{2} \mathrm{O}_{3}$, which account for about $70 \%$ of the total content.

Table 2. The chemical components of copper slag and stainless steel slag (wt $\%$ ).

\begin{tabular}{cccccccccc}
\hline Samples & $\mathrm{SiO}_{2}$ & $\mathrm{Fe}_{2} \mathrm{O}_{3}$ & $\mathrm{Al}_{2} \mathrm{O}_{3}$ & $\mathrm{CaO}$ & $\mathbf{M g O}$ & $\mathrm{Cr}_{2} \mathrm{O}_{3}$ & $\mathrm{CuO}$ & $\mathrm{ZnO}$ & $\mathrm{NiO}$ \\
\hline Copper slag & 33.44 & 52.69 & 5.68 & 2.90 & 2.03 & 0.24 & 0.24 & 2.01 & - \\
Steel slag & 38.61 & 7.32 & 9.52 & 16.03 & 8.07 & 14.57 & 0.03 & 0.01 & 0.71 \\
\hline
\end{tabular}

Figure 1 shows the XRD patterns of copper slag and stainless steel slag of EAF, respectively. It indicates that the main crystalline phases of copper slag are $\mathrm{Fe}_{2} \mathrm{SiO}_{4}$ and $\mathrm{Fe}_{3} \mathrm{O}_{4}$. The stainless steel slag mainly consists of spinels, such as $\mathrm{FeCr}_{2} \mathrm{O}_{4}, \mathrm{MgCr}_{2} \mathrm{O}_{4}, \mathrm{NiCr}_{2} \mathrm{O}_{4}$, and $\mathrm{Fe}_{3} \mathrm{O}_{4}$, which is consistent with previous studies [7,9,13-15].

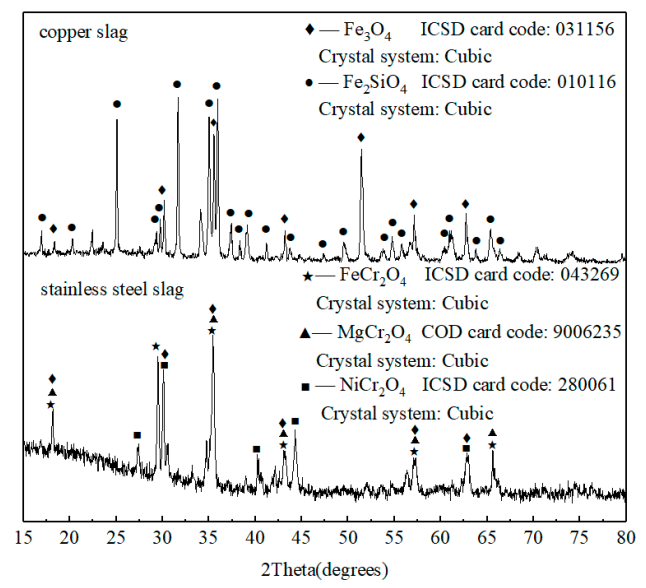

Figure 1. X-ray diffraction (XRD) patterns of waste copper slag and stainless steel slag. 


\subsubsection{Thermogravimetric Analysis}

Thermogravimetric curves of copper slag and stainless steel slag are shown in Figure 2. The results show that the mass of copper slag decreases with increasing temperature below $310^{\circ} \mathrm{C}$, mainly due to the presence of moisture in the slag and the dehydration reaction of the crystalline hydrate in the copper slag. The mass of the copper slag increases with the temperature above $310^{\circ} \mathrm{C}$, which is mainly due to the oxidation of $\mathrm{Fe}_{2} \mathrm{SiO}_{4}$ and $\mathrm{Fe}_{3} \mathrm{O}_{4}$ in the slag and the chemical reaction are as shown in the Equations (1) and (2) $[6,7,9]$. The mass of the stainless steel slag of EAF increases with temperature after $500{ }^{\circ} \mathrm{C}$ possibly due to the oxidation of $\mathrm{Fe}_{3} \mathrm{O}_{4}$ in the slag.

$$
\begin{array}{ll}
2 \mathrm{Fe}_{2} \mathrm{SiO}_{4}+\mathrm{O}_{2} \rightarrow 2 \mathrm{Fe}_{2} \mathrm{O}_{3}+2 \mathrm{SiO}_{2} & \Delta G^{\theta}=-501646+201.7 \mathrm{~T}(\mathrm{~J} / \mathrm{mol}) \\
4 \mathrm{Fe}_{3} \mathrm{O}_{4}+\mathrm{O}_{2} \rightarrow 6 \mathrm{Fe}_{2} \mathrm{O}_{3} & \Delta G^{\theta}=-477658+277.2 T(\mathrm{~J} / \mathrm{mol})
\end{array}
$$

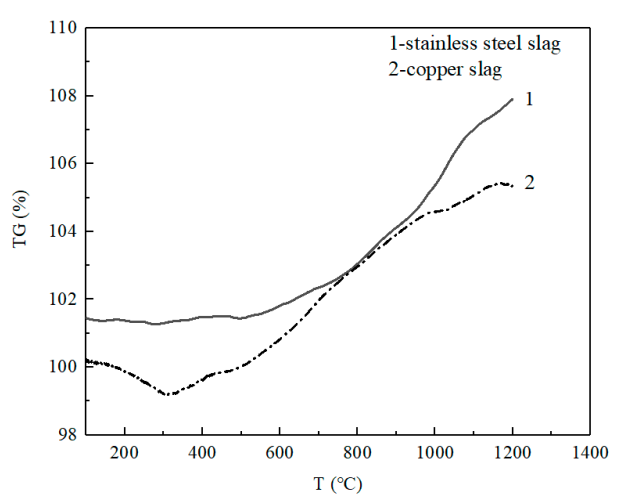

Figure 2. Thermogravimetric curves of copper slag and stainless steel slag of electric arc furnace (EAF).

\subsection{Effect of Fe/Cr Molar Ratio on the Coloration Performance of Ceramic Tiles}

Figures 3 and 4 show the photograph of the ceramic tile samples sintered at different Fe/Cr molar ratios and the XRD patterns of ceramic tiles prepared under different $\mathrm{Fe} / \mathrm{Cr}$ molar ratios, respectively. It can be found in Figure 3 that the color of ceramic tiles become darker as the $\mathrm{Fe} / \mathrm{Cr}$ molar ratios increased from 0.5 to 2.0. Moreover, there are no cracks or defects on the surface of ceramic tiles. However, when the $\mathrm{Fe} / \mathrm{Cr}=2.5$, the tile surface is slightly expanded. As shown in Figure 4, the chromite spinel $\left(\mathrm{FeCr}_{2} \mathrm{O}_{4}\right)$ is the main crystalline phase of black ceramic tile samples prepared at $1150{ }^{\circ} \mathrm{C}$. Moreover, $\mathrm{Cr}_{1.3} \mathrm{Fe}_{0.7} \mathrm{O}_{3}$ also present in the ceramic tile samples, which is formed by the reaction of $\mathrm{Fe}_{2} \mathrm{O}_{3}$ and $\mathrm{Cr}_{2} \mathrm{O}_{3}$. Meanwhile, $\mathrm{CaMgSi}_{2} \mathrm{O}_{6}$ exists as a minor component. With the increase of $\mathrm{Fe} / \mathrm{Cr}$ molar ratio, the contents of $\mathrm{Cr}_{1.3} \mathrm{Fe}_{0.7} \mathrm{O}_{3}$ and $\mathrm{FeCr}_{2} \mathrm{O}_{4}$ increase, whereas the content of $\mathrm{Fe}_{2} \mathrm{O}_{3}$ decreases, possibly due to the further reaction of $\mathrm{Fe}_{2} \mathrm{O}_{3}$ and $\mathrm{Cr}_{2} \mathrm{O}_{3}$ in the mixture to form $\mathrm{Cr}_{1.3} \mathrm{Fe}_{0.7} \mathrm{O}_{3}$ and $\mathrm{FeCr}_{2} \mathrm{O}_{4}$.

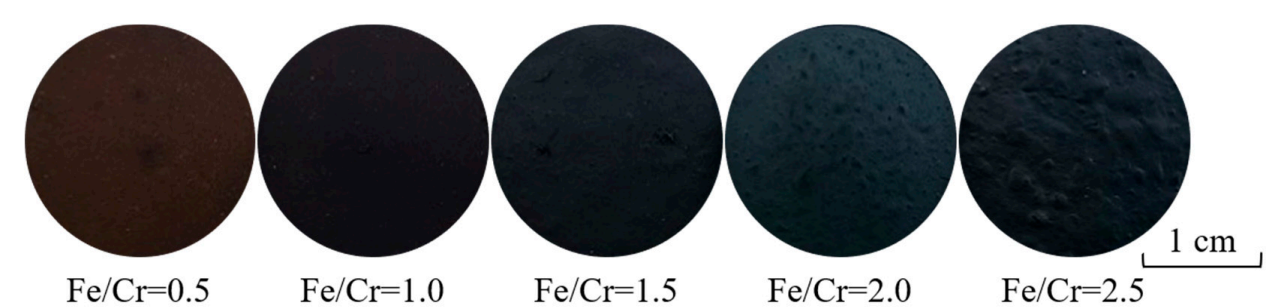

Figure 3. Ceramic tile samples with different $\mathrm{Fe} / \mathrm{Cr}$ molar ratio sintered at $1150{ }^{\circ} \mathrm{C}$ for $30 \mathrm{~min}$.

Figure 5 shows the effects of the $\mathrm{Fe} / \mathrm{Cr}$ molar ratio on the coloration of ceramic tiles. As the $\mathrm{Fe} / \mathrm{Cr}$ molar ratio increases, the $L^{*}$ value decreases firstly. This is because the increased $\mathrm{Fe}_{2} \mathrm{O}_{3}$ content in the material reacts with $\mathrm{Cr}_{2} \mathrm{O}_{3}$ to generate large amounts of $\mathrm{Cr}_{1.3} \mathrm{Fe}_{0.7} \mathrm{O}_{3}$ and $\mathrm{FeCr}_{2} \mathrm{O}_{4}$. Therefore, it enhances the black chromaticity value of the ceramic tile. Moreover, note that when the $\mathrm{Fe} / \mathrm{Cr}$ molar 
ratio is higher than 1.0, $L^{*}$ value increases gradually. This is possibly due to that the increased $\mathrm{Fe}_{2} \mathrm{O}_{3}$ and $\mathrm{Cr}_{2} \mathrm{O}_{3}$ reaction at this time mainly generate $\mathrm{Cr}_{1.3} \mathrm{Fe}_{0.7} \mathrm{O}_{3}$, while $\mathrm{FeCr}_{2} \mathrm{O}_{4}$ content is relatively less than that in $\mathrm{Fe} / \mathrm{Cr}=1.0$, and weakens the black chromaticity value of the ceramic tile.

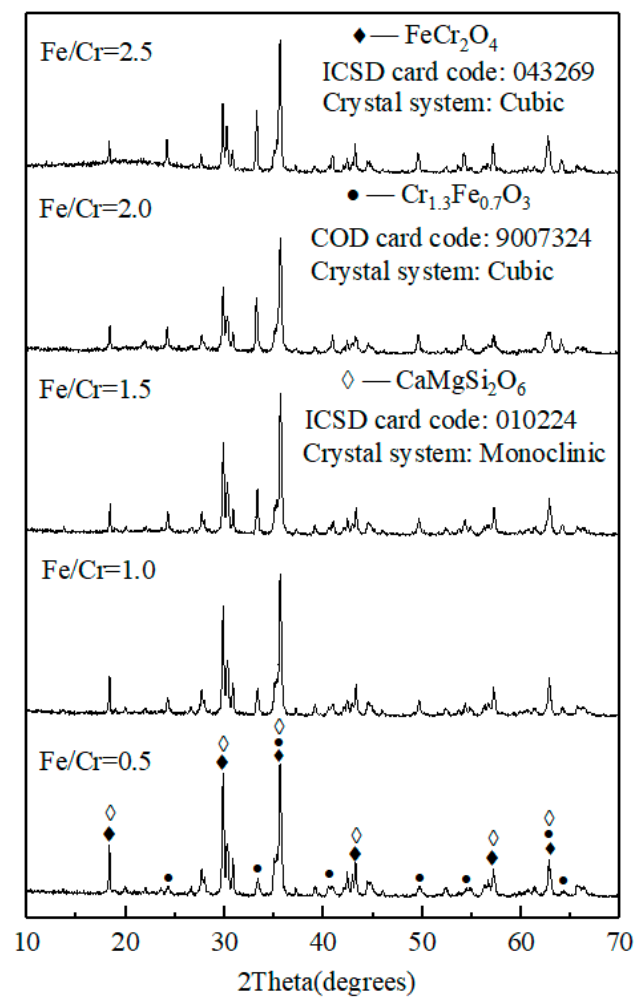

Figure 4. XRD patterns of ceramic tiles with different $\mathrm{Fe} / \mathrm{Cr}$ molar ratio sintered at $1150{ }^{\circ} \mathrm{C}$ for $30 \mathrm{~min}$.

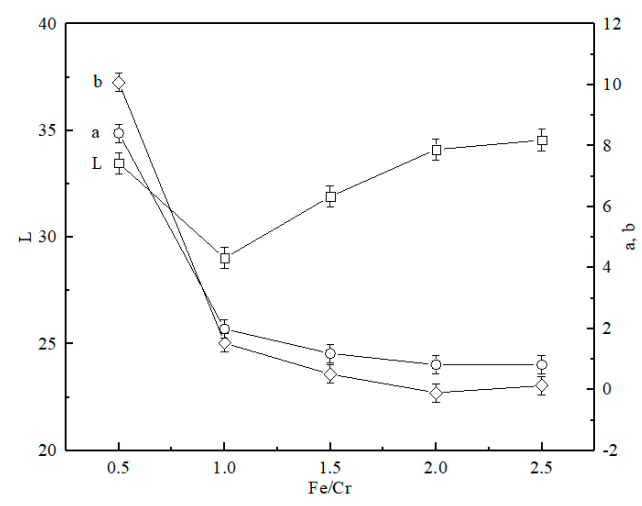

Figure 5. Effects of Fe/Cr molar ratio on the coloration of ceramic tiles sintered at $1150{ }^{\circ} \mathrm{C}$ for $30 \mathrm{~min}$.

As the $\mathrm{Fe} / \mathrm{Cr}$ molar ratio increase in the materials, the values of $+a^{*}$ and $+b^{*}$ gradually decrease. The ceramic tile sample becomes reddish with the increasing of $+a^{*}$ value. This may be due to the presence of small amounts of unreacted $\mathrm{Fe}_{2} \mathrm{O}_{3}$ in the ceramic tile. A larger value of $+b^{*}$ indicates that the sample is yellowish and certain amounts of $\mathrm{Ca}$ are contained in ceramic tiles, which may influence the coloration of $\mathrm{Fe}^{3+}$ to make it brownish [29].

Therefore, the optimum Fe/Cr molar ratio of the mixed slag material for better coloration performance is 2.0, after considering the changes in the values of $L^{*}, a^{*}$, and $b^{*}$ of black ceramic tile and the contents of $\mathrm{Cr}_{1.3} \mathrm{Fe}_{0.7} \mathrm{O}_{3}$ and $\mathrm{FeCr}_{2} \mathrm{O}_{4}$. 


\subsection{Effect of Sintering Temperature on the Coloration Performance of Ceramic Tiles}

Figures 6 and 7 show the photograph of ceramic tile samples sintered at different sintering temperatures and the XRD patterns of ceramic tiles prepared under different sintering temperatures, respectively. It was found in Figure 6 that as the sintering temperature increases from $1100{ }^{\circ} \mathrm{C}$ to $1150^{\circ} \mathrm{C}$, the color of ceramic tile becomes become darker. The ceramic tile is black and smooth after being sintered at $1125^{\circ} \mathrm{C}, 1150{ }^{\circ} \mathrm{C}$, and $1175^{\circ} \mathrm{C}$. However, when the sintering temperature increases to $1200{ }^{\circ} \mathrm{C}$, the ceramic tiles become bulging deformation. As shown in Figure 7, the main phases of ceramic tiles are $\mathrm{FeCr}_{2} \mathrm{O}_{4}, \mathrm{CaMgSi}_{2} \mathrm{O}_{6}$, and $\mathrm{Cr}_{1.3} \mathrm{Fe}_{0.7} \mathrm{O}_{3}$. As the sintering temperature increases, the contents of $\mathrm{Cr}_{1.3} \mathrm{Fe}_{0.7} \mathrm{O}_{3}$ and $\mathrm{CaMgSi}_{2} \mathrm{O}_{6}$ firstly increase and then decrease, while the $\mathrm{FeCr}_{2} \mathrm{O}_{4}$ firstly decreases and then increases. Meanwhile, when the sintering temperature rises to $1200{ }^{\circ} \mathrm{C}$ or even higher, more liquid phases will be formed in the ceramic tile and could dramatically lead to the dissolution of the $\mathrm{Cr}_{1.3} \mathrm{Fe}_{0.7} \mathrm{O}_{3}$ [29], which is not conducive to ceramic tile production.

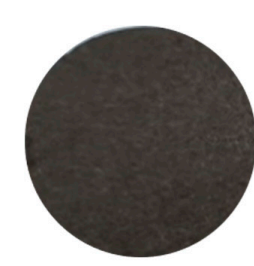

$1100{ }^{\circ} \mathrm{C}$

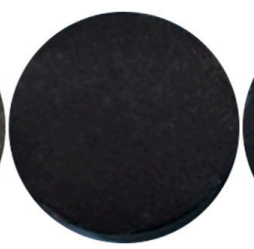

$1125^{\circ} \mathrm{C}$

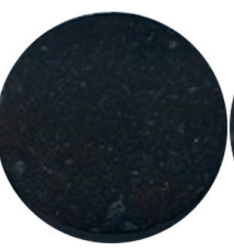

$1150^{\circ} \mathrm{C}$

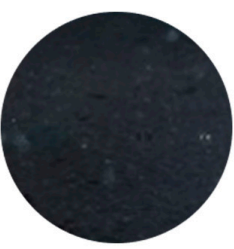

$1175^{\circ} \mathrm{C}$

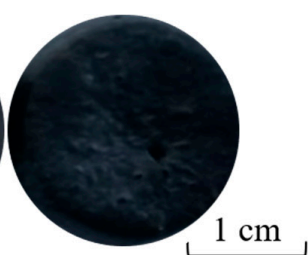

$1200{ }^{\circ} \mathrm{C}$

Figure 6. Ceramic tile samples with $\mathrm{Fe} / \mathrm{Cr}=2.0$ sintered at different temperatures for $30 \mathrm{~min}$.

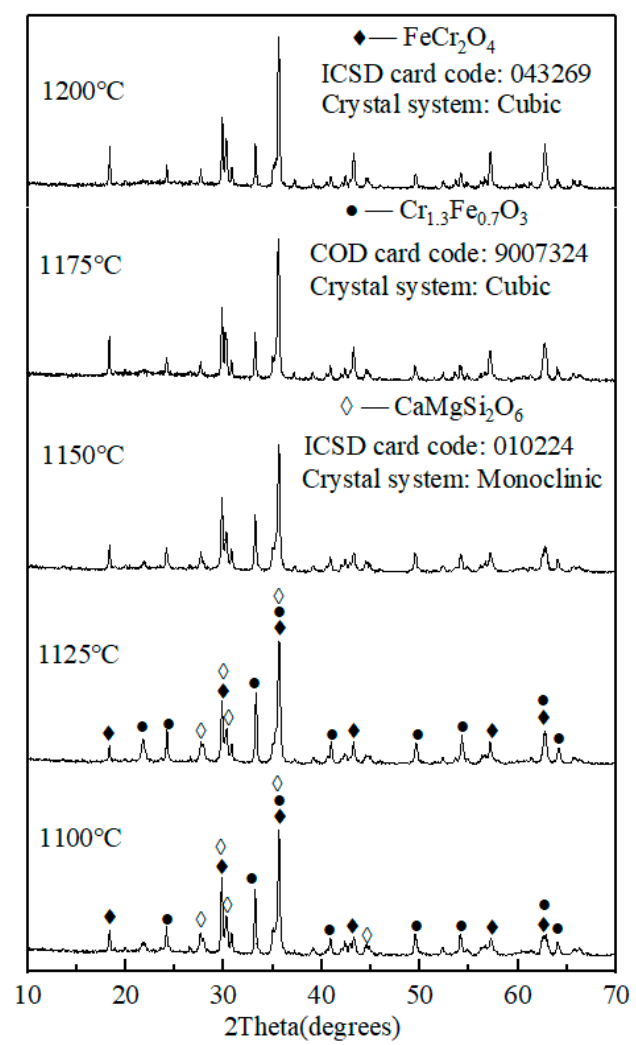

Figure 7. XRD patterns of ceramic tiles with $\mathrm{Fe} / \mathrm{Cr}=2.0$ sintered at different temperatures for $30 \mathrm{~min}$.

Figure 8 shows the effects of sintering temperature on the coloration performance of ceramic tiles. As the sintering temperature increases, the $L^{*}$ value decreases firstly and then increases. At $1150{ }^{\circ} \mathrm{C}$, the $L^{*}$ value of ceramic tile is the smallest. With the increase of sintering temperature, the values of $a^{*}$ and $b^{*}$ decrease. Moreover, the value of $a^{*}$ attains the minimum at $1175^{\circ} \mathrm{C}$ and keeps stable, and when 
the sintering temperature is higher than $1125^{\circ} \mathrm{C}$, the $b^{*}$ value remains low with the further increase of sintering temperature. It is mainly due to the fact that the increase of temperature increases the chemical reaction ability and diffusion ability of solid particles, the $\mathrm{Fe}_{2} \mathrm{O}_{3}$, and $\mathrm{Cr}_{2} \mathrm{O}_{3}$ in the mixture react to form a large amount of $\mathrm{FeCr}_{2} \mathrm{O}_{4}$ and $\mathrm{Cr}_{1.3} \mathrm{Fe}_{0.7} \mathrm{O}_{3}$, which enhances the black chromaticity value of the ceramic tile. In addition, as the sintering temperature further increases, the reaction of $\mathrm{Fe}_{2} \mathrm{O}_{3}$ and $\mathrm{Cr}_{2} \mathrm{O}_{3}$ in the mixture mainly generates $\mathrm{FeCr}_{2} \mathrm{O}_{4}$, while the content of $\mathrm{Cr}_{1.3} \mathrm{Fe}_{0.7} \mathrm{O}_{3}$ is relatively low, which weakens the black chromaticity value of the black ceramic tile.

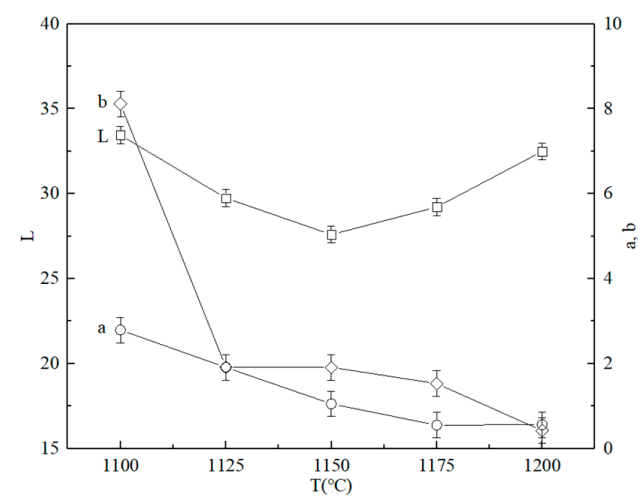

Figure 8. Effects of sintering temperature on the coloration of ceramic tiles with $\mathrm{Fe} / \mathrm{Cr}=2.0$ sintered for $30 \mathrm{~min}$.

Figure 9 shows the microstructure of black ceramic tiles sintered at $1100{ }^{\circ} \mathrm{C}$ and $1150{ }^{\circ} \mathrm{C}$. It can be seen from Figure 9 that there are a lot of micropores in the ceramic tile fired at $1100{ }^{\circ} \mathrm{C}$. When fired at $1150^{\circ} \mathrm{C}$, the number of micropores decreases and the oxide phases of iron and chromium are evenly distributed. The results show that increasing sintering temperature can promote the sintering reaction of the black ceramic tile, in particular, an appropriate amount of liquid phase can be generated to reduce the porosity, thereby improving the surface quality and coloration performance of the black ceramic tile.
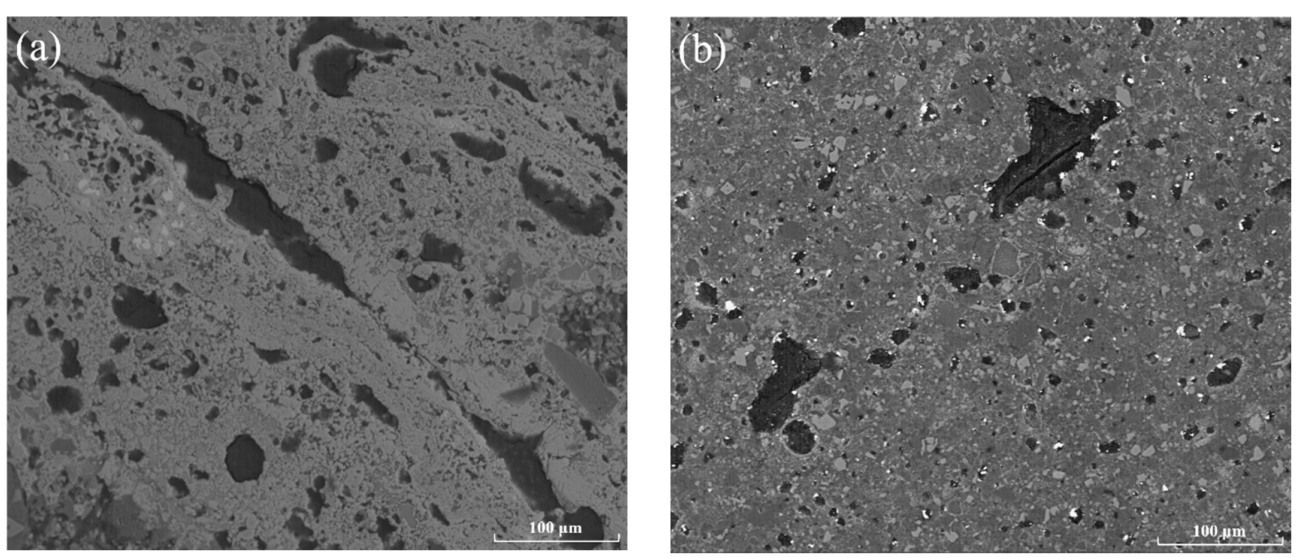

Figure 9. SEM images of ceramic tiles with $\mathrm{Fe} / \mathrm{Cr}=2.0$ sintered at different temperatures for $30 \mathrm{~min}$ (a) $1100{ }^{\circ} \mathrm{C}$ and (b) $1150{ }^{\circ} \mathrm{C}$.

Therefore, the optimum sintering temperature is $1150{ }^{\circ} \mathrm{C}$, after considering the changes in the values of $L^{*}, a^{*}$, and $b^{*}$, the contents of $\mathrm{Cr}_{1.3} \mathrm{Fe}_{0.7} \mathrm{O}_{3}$ and $\mathrm{FeCr}_{2} \mathrm{O}_{4}$ and the microstructure of black ceramic tile. 


\subsection{Effects of Sintering Time on the Coloration Performance of Ceramic Tiles}

Figures 10 and 11 show the photograph of ceramic tile samples sintered at different sintering time and the XRD diagrams of black ceramic tiles prepared under different sintering times, respectively. It was found in Figure 10 that the color of ceramic tiles is dark as the sintering temperature increases from $15 \mathrm{~min}$ to $90 \mathrm{~min}$. The surface of ceramic tiles is smooth and black with uniform coloration. As shown in Figure 10, at the sintering temperature of $1150{ }^{\circ} \mathrm{C}$ for sintering time ranged from 15 to $90 \mathrm{~min}$, the main phases of ceramic tile are $\mathrm{FeCr}_{2} \mathrm{O}_{4}, \mathrm{CaMgSi}_{2} \mathrm{O}_{6}$ and $\mathrm{Cr}_{1.3} \mathrm{Fe}_{0.7} \mathrm{O}_{3}$. The results show that under the sintering temperature of $1150{ }^{\circ} \mathrm{C}$, the chemical reaction of the ceramic tile reacts completely within a short time.

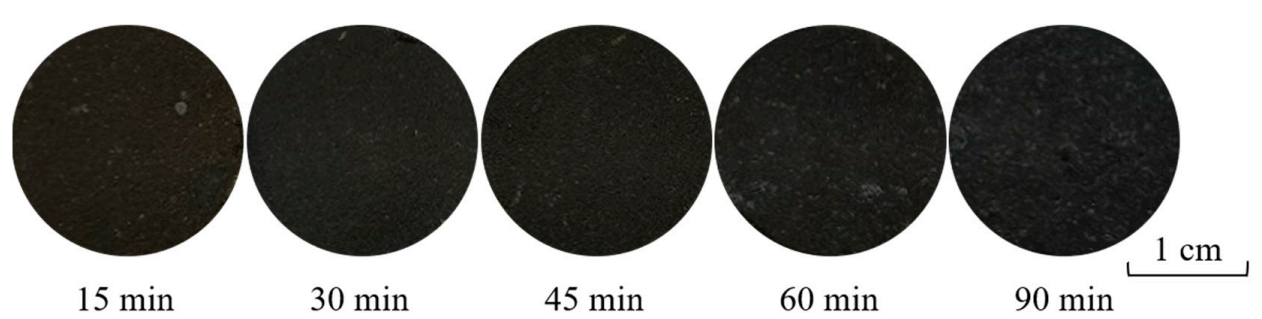

Figure 10. Ceramic tile samples with $\mathrm{Fe} / \mathrm{Cr}=2.0$ sintered at $1150{ }^{\circ} \mathrm{C}$ for different time.

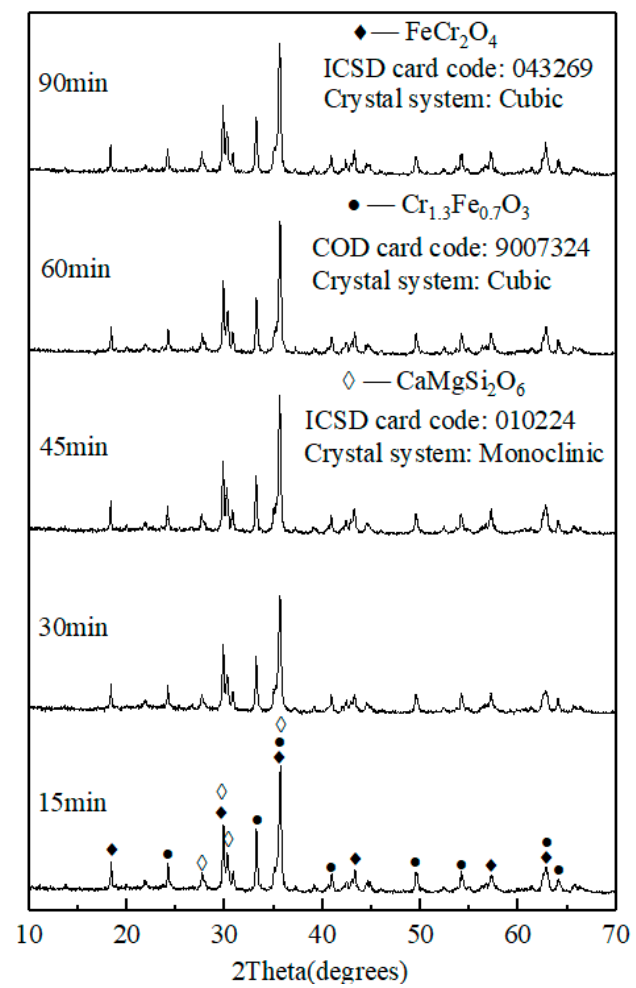

Figure 11. XRD patterns of ceramic tiles with $\mathrm{Fe} / \mathrm{Cr}=2.0$ sintered at $1150{ }^{\circ} \mathrm{C}$ for different time.

The effects of sintering time on the ceramic tile color are related to the reaction of the coloring ions with the ceramic matrix. Figure 12 shows the effects of sintering time on the coloration performance of black ceramic tiles. As shown in Figure 12, when the sintering temperature is $1150{ }^{\circ} \mathrm{C}$, the $L^{*}, a^{*}$, and $b^{*}$ of the black ceramic tile generally decrease with the increase of the sintering time. The $b^{*}$ of the black ceramic tile is slightly increased, i.e., the tile surface is yellowish-brown, possibly due to the oxidation of iron oxides [31].

Therefore, the optimum sintering time is $30 \mathrm{~min}$, after considering the changes in the values of $L^{*}$, $a^{*}$ and $b^{*}$ and the phase compositions of black ceramic tile. 


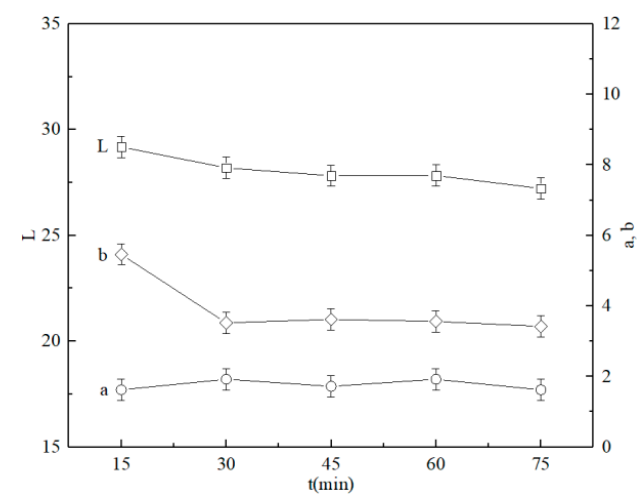

Figure 12. Effects of sintering time on the coloration of ceramic tiles with $\mathrm{Fe} / \mathrm{Cr}=2.0$ sintered at $1150{ }^{\circ} \mathrm{C}$.

\subsection{Compression and Leaching Tests of Ceramic Tiles}

Table 3 shows the compression test results of black ceramic tiles. The results show that as the $\mathrm{Fe} / \mathrm{Cr}$ increases, the compressive strength of the black ceramic tile increases gradually sintering at $1150{ }^{\circ} \mathrm{C}$ for $30 \mathrm{~min}$. At the sintering temperature range from $1100{ }^{\circ} \mathrm{C}$ to $1200{ }^{\circ} \mathrm{C}$, the compressive strength increases firstly and then decreases. This is due to the fact that when the sintering temperature rises to $1200{ }^{\circ} \mathrm{C}$ or even higher, it can lead to overburning of the ceramic tile, resulting in cracks on the ceramic tile surface and reduction of compressive strength. In addition, it attains a maximum value of $50.58 \mathrm{MPa}$ at $1150^{\circ} \mathrm{C}$. Moreover, as the sintering time increases, the compressive strength of black ceramic tiles decreases. Note that when the $\mathrm{Fe} / \mathrm{Cr}$ molar ratio of 2.0, sintering temperature of $1150{ }^{\circ} \mathrm{C}$, and sintering time of $30 \mathrm{~min}$, the compressive strength of black ceramic tile is $50.58 \mathrm{MPa}$, which exceeds the minimum compressive strength of $27 \mathrm{MPa}$ of the Chinese national standard (GB/T4100-2006) [32] for standard polished tiles.

The leaching toxicity results of the ceramic tile with $\mathrm{Fe} / \mathrm{Cr}=2.0$ sintered at $1150{ }^{\circ} \mathrm{C}$ for $30 \mathrm{~min}$ are shown in Table 4. The results show that the concentrations of harmful elements such as $\mathrm{Cr}, \mathrm{As}, \mathrm{Zn}, \mathrm{Pb}$, and $\mathrm{Cr}(\mathrm{VI})$, can meet the regulation thresholds specified by the national standard (GB 5085.3-2007) [33]. Therefore, the use of copper slag and stainless steel slag of EAF to prepare black ceramic tile is a safe and value-added process that can harmlessly recycle waste slag.

Table 3. Compressive strength of ceramic tile at different sintering conditions (MPa).

\begin{tabular}{ccc}
\hline No. & Sintering Conditions & Compressive Strength \\
\hline 1 & $\mathrm{Fe} / \mathrm{Cr}=1.01150{ }^{\circ} \mathrm{C} 30 \mathrm{~min}$ & 21.71 \\
2 & $\mathrm{Fe} / \mathrm{Cr}=1.51150{ }^{\circ} \mathrm{C} 30 \mathrm{~min}$ & 30.09 \\
3 & $\mathrm{Fe} / \mathrm{Cr}=2.01150{ }^{\circ} \mathrm{C} 15 \mathrm{~min}$ & 58.12 \\
4 & $\mathrm{Fe} / \mathrm{Cr}=2.01150{ }^{\circ} \mathrm{C} 30 \mathrm{~min}$ & 50.58 \\
5 & $\mathrm{Fe} / \mathrm{Cr}=2.01100{ }^{\circ} \mathrm{C} 30 \mathrm{~min}$ & 21.36 \\
6 & $\mathrm{Fe} / \mathrm{Cr}=2.0120{ }^{\circ} \mathrm{C} 30 \mathrm{~min}$ & 8.23 \\
7 & $\mathrm{Fe} / \mathrm{Cr}=2.01150{ }^{\circ} \mathrm{C} 45 \mathrm{~min}$ & 23.68 \\
\hline
\end{tabular}

Table 4. Concentrations of leachable elements from tiles sintered with $\mathrm{Fe} / \mathrm{Cr}=2.0$ at $1150{ }^{\circ} \mathrm{C}$ and $30 \mathrm{~min}(\mathrm{mg} / \mathrm{L})$.

\begin{tabular}{cccccccc}
\hline Leachable Elements & $\mathbf{C r}$ & $\mathbf{C u}$ & $\mathbf{N i}$ & $\mathrm{As}$ & $\mathbf{Z n}$ & $\mathbf{P b}$ & $\mathbf{C r}(\mathbf{V I})$ \\
\hline Ceramic tile samples & 2.35 & 0.45 & 0.14 & 0.082 & 1.59 & 0.19 & 0.024 \\
GB 5085.3-2007 & 15 & 100 & 5 & 5 & 100 & 5 & 5 \\
\hline
\end{tabular}

\section{Conclusions}

This study provides a new way to develop low-cost, high-quality, environmentally friendly black ceramic tile, and achieves the harmless and value-added utilization of copper slag and stainless steel 
slag of EAF. The black ceramic tiles can be used in the building and decoration industries. Its application prospect is relatively broad.

(1) The optimum process parameters for the preparation of black ceramic tile from copper slag and EAF stainless steel slag are $\mathrm{Fe} / \mathrm{Cr}=2.0$, the sintering temperature of $1150{ }^{\circ} \mathrm{C}$, and sintering time of $30 \mathrm{~min}$.

(2) The main crystalline phases of the black ceramic tile prepared under the optimum process parameters are chromite spinel $\left(\mathrm{FeCr}_{2} \mathrm{O}_{4}\right)$ and solid solution oxide $\left(\mathrm{Cr}_{1.3} \mathrm{Fe}_{0.7} \mathrm{O}_{3}\right)$, with fewer micropores and more uniform distribution of iron and chromium oxide phase.

(3) Under the optimum technological parameters, the surface of ceramic tiles is smooth and black with uniform coloration $\left(L^{*}=+28.19, a^{*}=+1.71\right.$ and $\left.b^{*}=+3.52\right)$. The compressive strength of the black ceramic tiles exceeds the minimum compressive strength of the Chinese national standard for standard polished tiles, and the concentrations of harmful elements such as $\mathrm{Cr}, \mathrm{Cu}, \mathrm{Ni}, \mathrm{As}, \mathrm{Zn}, \mathrm{Pb}$, and $\mathrm{Cr}(\mathrm{VI})$ are within the regulation thresholds specified by the national standard.

Author Contributions: Conceptualization, G.M.; Methodology, M.L.; Validation, M.L. and G.M.; Formal Analysis, M.L. and X.Z.; Investigation M.L., X.Z., and J.L.; Resources, M.L. and G.M.; Data curation, J.L. and Q.W.; Writing-Original Draft Preparation, M.L.; Writing—Review Editing, G.M.; Visualization, M.L.; Supervision, G.M.; Project Administration, G.M.; Funding Acquisition, G.M. All authors have read and agreed to the published version of the manuscript.

Funding: This research was funded by the Joint Research Fund of the National Natural Science Foundation-China BaoWu Steel Group Co., Ltd [grant numbers U1960108], the National Natural Science Foundation of China [grant numbers 51904212], and Hubei Provincial Special Project on Technology Innovation (Foreign Scientific and Technological Cooperation) [grant numbers 2017AHB042].

Conflicts of Interest: The authors declare no conflicts of interest.

\section{References}

1. Mineral Commodity Summaries. Copper. Available online: https://prd-wret.s3-us-west-2.amazonaws.com/ assets/palladium/production/s3fs-public/atoms/files/mcs-2019-coppe.pdf (accessed on 28 August 2019).

2. ICSG Raises 2019 Copper Deficit Prediction. Available online: https://investingnews.com/daily/ resource-investing/base-metals-investing/copper-investing/icsg-raises-copper-deficit-prediction/ (accessed on 28 August 2019).

3. ICSG Press Release: Copper Market Forecast 2019/2020. Available online: https://recyclingportal.eu/Archive/ 48147 (accessed on 28 August 2019).

4. Rajasekar, A.; Arunachalam, K.; Kottaisamy, M. Assessment of strength and durability characteristics of copper slag incorporated ultra high strength concrete. J. Cleaner Prod. 2019, 208, 402-414. [CrossRef]

5. Prem, P.R.; Verma, M.; Ambily, P.S. Sustainable cleaner production of concrete with high volume copper slag. J. Cleaner Prod. 2018, 193, 43-58. [CrossRef]

6. Gorai, B.; Jana, R.K.; Premchand. Characteristics and utilisation of copper slag-a review. Resour., Conserv. Recycl. 2003, 39, 299-313. [CrossRef]

7. Fan, Y.; Shibata, E.; Iizuka, A.; Nakamura, T. Crystallization behaviors of copper smelter slag studied using time-temperature-transformation diagram. Mater. Trans. 2014, 55, 958-963. [CrossRef]

8. Feng, Y.; Kero, J.; Yang, Q.; Chen, Q.; Engström, F.; Samuelsson, C.; Qi, C. Mechanical activation of granulated copper slag and its influence on hydration heat and compressive strength of blended cement. Materials 2019, 12, 772. [CrossRef] [PubMed]

9. Fan, Y.; Shibata, E.; Iizuka, A.; Nakamura, T. Crystallization behavior of copper smelter slag during molten oxidation. Metall. Mater. Trans. B 2015, 46, 2158-2164. [CrossRef]

10. Holland, K.; Eriç, R.H.; Taskinen, P.; Jokilaakso, A. Upgrading copper slag cleaning tailings for re-use. Miner. Eng. 2019, 133, 35-42. [CrossRef]

11. Stainless Steel Production Reached 50.7 Million Metric Tons in 2018. Available online: http://www. worldstainless.org/news/show/2351 (accessed on 28 August 2019).

12. Li, J.; Mou, Q.; Zeng, Q.; Yu, Y. Experimental study on precipitation behavior of spinels in stainless steel-making slag under heating treatment. Processes 2019, 7, 487. [CrossRef] 
13. Fathy, S.; Guo, L.; Ma, R.; Gu, C.; Sun, W. Properties of steel slag and stainless steel slag as cement replacement materials: A comparative study. J. Wuhan Univ. Technol., Mater. Sci. Ed. 2018, 33, 1444-1451.

14. Wu, T.; Zhang, Y.; Zhao, Z.; Yuan, F. Effects of $\mathrm{Fe}_{2} \mathrm{O}_{3}$ on reduction process of Cr-containing solid waste self-reduction briquette and relevant mechanism. Metals 2019, 9, 51. [CrossRef]

15. Fan, W.; Yang, Q.; Guo, B.; Zhang, S. Crystallization mechanism of glass-ceramics prepared from stainless steel slag. Rare Met. 2018, 37, 413-420. [CrossRef]

16. Zeng, Q.; Li, J.; Mou, Q.; Zhu, H.; Xue, Z. Effect of FeO on spinel crystallization and chromium stability in stainless steel-making slag. JOM. 2019, 71, 2331-2337. [CrossRef]

17. Galan-Arboledas, R.J.; Alvarez de Diego, J.; Dondi, M.; Bueno, S. Energy, environmental and technical assessment for the incorporation of EAF stainless steel slag in ceramic building materials. J. Cleaner Prod. 2017, 142, 1778-1788. [CrossRef]

18. Davydenko, A.; Karasev, A.; Glaser, B.; Jönsson, P. Direct reduction of Fe, Ni and Cr from oxides of waste products used in briquettes for slag foaming in EAF. Materials 2019, 12, 3434. [CrossRef] [PubMed]

19. Zhang, H.; Hong, X. An overview for the utilization of wastes from stainless steel industries. Resour. Conserv. Recycl. 2011, 55, 745-754.

20. Zhu, R.; Ma, G.; Cai, Y.; Chen, Y.; Yang, T.; Duan, B.; Xue, Z. Ceramic tiles with black pigment made from stainless steel plant dust: Physical properties and long-term leaching behavior of heavy metals. J. Air Waste Manage. Assoc. 2016, 66, 402-411. [CrossRef]

21. Llusar, M.; Bermejo, T.; Primo, J.E.; Gargori, C.; Esteve, V.; Monrós, G. Karrooite green pigments doped with Co and Zn: Synthesis, color properties and stability in ceramic glazes. Ceram. Int. 2017, 43, 9133-9144. [CrossRef]

22. Dondi, M.; Zanelli, C.; Ardit, M.; Cruciani, G.; Mantovani, L.; Tribaudino, M.; Andreozzi, G.B. Ni-free, black ceramic pigments based on Co-C-Fe-Mn spinels: A reappraisal of crystal structure, colour and technological behavior. Ceram. Int. 2013, 39, 9533-9547. [CrossRef]

23. Carneiro, J.; Tobaldi, D.M.; Capela, M.N.; Seabra, M.P.; Labrincha, J.A. Waste-Based pigments for application in ceramic glazes and stoneware bodies. Materials 2019, 12, 3396. [CrossRef]

24. Ovčačíková, H.; Vlček, J.; Klárová, M.; Topinková, M. Metallurgy dusts as a pigment for glazes and engobes. Ceram. Int. 2017, 43, 7789-7796. [CrossRef]

25. Du, M.; Du, Y.; Chen, Z.; Li, Z.; Yang, K.; Lv, X.; Feng, Y. Synthesis and characterization of black ceramic pigments by recycling of two hazardous wastes. Appl. Phys. A: Mater. Sci. Process. 2017, 123, 574-581. [CrossRef]

26. Chen, Y.; Zhang, Y.; Chen, T.; Liu, T.; Huang, J. Preparation and characterization of red porcelain tiles with hematite tailings. Constr. Build. Mater. 2013, 38, 1083-1088. [CrossRef]

27. Tanisana, B.; Turanb, S. Black ceramic pigments for porcelain tile bodies produced with chromite ores and iron oxide waste. J. Ceram. Process. Res. 2011, 12, 462-467.

28. Zhao, L.; Li, Y.; Zhou, Y.; Cang, D. Preparation of novel ceramics with high CaO content from steel slag. Mater. Des. 2014, 64, 608-613. [CrossRef]

29. Zhang, X.; Ma, G.; Jin, Y.; Cheng, P. Preparation of ceramic tiles with black pigments using stainless steel plant dust as a raw material. Ceram. Int. 2014, 40, 9693-9700. [CrossRef]

30. Solid waste-Extraction procedure for leaching toxicity-Sulphuric acid nitric acid method; HJ/T299-2007; China Environmental Press: Beijing, China, 2007.

31. Corradi, A.B.; Leonelli, C.; Manfredini, T.; Pozzo, P.; Romagnoli, M. Preparation and properties of fast-fired porcelain tiles containing natural Chromite. Am. Ceram. Soc. Bull. 1993, 72, 63-69.

32. Ceramic Tiles; GB/T4100-2006; General Administration of Quality Supervision, Inspection and Quarantine of the People's Republic of China: Beijing, China, 2006.

33. Identification Standards for Hazardous Wastes-Identification for Extraction Toxicity; GB 5085.3-2007; General Administration of Quality Supervision, Inspection and Quarantine of the People's Republic of China: Beijing, China, 2007.

(C) 2020 by the authors. Licensee MDPI, Basel, Switzerland. This article is an open access article distributed under the terms and conditions of the Creative Commons Attribution (CC BY) license (http://creativecommons.org/licenses/by/4.0/). 